\title{
The Chloroplast psbK-psbI Intergenic Region, a Potential Genetic Marker for Broad Sectional Relationships in Anthurium
}

\author{
Jon Y. Suzuki', Tracie K. Matsumoto, Lisa M. Keith, \\ and Roxana Y. Myers \\ USDA, ARS, Daniel K. Inouye U.S. Pacific Basin Agricultural Research \\ Center, Tropical Plant Genetic Resources and Disease Research Unit, 64 \\ Nowelo Street, Hilo, HI 96720
}

Additional index words. Araceae, barcode, CBOL, genotyping, germplasm, ornamentals, phylogeny, sectional groupings

\begin{abstract}
Nuclear and chloroplast genetic markers have been extensively used for plant identification and molecular taxonomy studies. The efficacy of genetic markers to be used as DNA barcodes is under constant evaluation and improvement with identification of new barcodes that provide greater resolution and efficiency of amplification for specific species groups as well as distantly related plants. In this study, chloroplast DNA genetic markers for Anthurium, the largest genus in the Araceae family, were adapted from chloroplast markers previously designed for Lemna minor, a member of the same plant family. Primers for chloroplast region trnH-psbA, previously used for molecular systematic studies in Anthurium, as well as primers for the $r p o B, r p o C 1, p s b K-p s b I, m a t K, r b c L$, and $a t p F-a t p H$ regions, all located within the large single copy sequence in the chloroplast genome, were evaluated and found to efficiently amplify target sequences when using DNA of varied quality and concentration extracted from silica-dried leaves of selected accessioned species of Anthurium. The $t r n H-p s b A, p s b K-p s b I$, and $a t p F-a t p H$ intergenic region primers were further evaluated using Anthurium species spanning different subgeneric groups. Of the intergenic region primers tested, $p s b K$-psbI primers were the most robust, yielding well-defined amplicons across Anthurium species that were consistent, with exceptions, within sectional groupings. Application of the $p s b K-p s b I$ region amplicon as a visual marker for surveying sectional relationships in Anthurium is novel and serves as a model for the development of a diagnostic method for genotyping plants and testing for sample integrity from among species or germplasm collections. This work further demonstrates the use of dried plant tissue banks as a genetic reference and information resource to support basic research as well as ornamental plant characterization and improvement.
\end{abstract}

Research at the USDA ARS Pacific Basin Agricultural Research Center (PBARC) Tropical Plant Genetic Resources and Disease Research unit in Hilo, HI, includes support for the improvement of tropical plant ornamental and fruit crops, including cut and potted Anthurium for the Hawaiian floral industry. Anthurium are the top cut flower in Hawaii with sales in 2012 of 348,000 dozen flower stems valued at $\$ 3.34$ million and 35,000 potted Anthurium were sold for a value of $\$ 267,000$ (USDA, National Agriculture Statistics Service and Hawaii Department of Agriculture Agricultural Development Division, 2013). The genus Anthurium, the largest of the Araceae family, is comprised of $\approx 905$ described species that range from southern Mexico to northern Argentina (Carlsen, 2011; Govaerts et al., 2014), but based on the number of estimated new species to be described, this figure may increase to 1500 taxa (T.B. Croat, unpublished data; Boyce and Croat, 2012). Many modern commercial Anthurium cultivars are derived from interfertile hybrids, mainly from species within section Calomystrium, including A. andraeanum,
A. amnicola, $A$. antioquiense, $A$. antrophyoides, $A$. armeniense, $A$. formosum, $A$. hoffmannii, $A$. kamemotoanum, and A. nymphaeifolium, as well as hybrids between species within the sections Porphyrochitonium and Cardiolonchium, and intersectional hybrids between Calomystrium and Cardiolonchium, among others (Kamemoto and Kuehnle, 1996). One of the ongoing research goals at PBARC is the development of molecular resources to identify origins of ornamental and horticultural diversity at the genome and molecular biological levels (Bliss and Suzuki, 2012) to support improvement of cultivars through breeding and biotechnological applications (Matsumoto et al., 2013).

In tropical ornamentals, including Anthurium, very few tools, simple or complex, for molecular evaluation of germplasm are available. Chloroplast gene markers have been used extensively for molecular identification in plants, although their use for species-level resolution is dependent on the genes used and the particular family of plants being studied (Shaw et al., 2005, 2007). Sequence analysis of the nuclear CHS gene intron and the chloroplast $\operatorname{trn} G$ intron, trnH-psbA, and trnC-ycf6 intergenic spacers in Anthurium has recently resulted in the reclassification and improved understanding of the various subgeneric sections and species relationships in this genus (Carlsen, 2011; Carlsen and Croat, 2013; Croat and Carlsen, 2013). This is the most comprehensive molecular phylogeny of Anthurium to date, providing a contemporary framework for identifying species, their origins, interrelationships, evolution, and diversification. Lemnaceae-specific chloroplast DNA markers for the rpoB, rpoC1, $m a t K$, and $r b c L$ gene regions, and the trnH-psbA, atpF-atpH, and $p s b K-p s b I$ intergenic regions were recently developed (Wang et al., 2010) based on a recommendation by the Consortium for the Barcode of Life (CBOL) (CBOL Plant Working Group, 2009), which allowed evaluation of DNA barcoding markers for species identification in this family.

In this study, we further explored the marker genes used in Lemna to supplement those presently used for molecular systematic studies in Anthurium as a result of their relatively close phylogenetic relationship (Rothwell et al., 2004). Although we did not have access to a large collection of live accessioned species of Anthurium, dried leaf material of species from previously identified collections was obtained from various sources and stored on silica. The goal of this study was to determine the appropriateness of using dried leaf material as the source of amplifiable DNA and for further development of diagnostic gene markers. Approaches for applying known phylogenetic information for practical diagnostic genotyping of $\mathrm{An}$ thurium species or germplasm in collections were also investigated.

\section{Materials and Methods}

DNA extraction from Anthurium plant leaves. Anthurium leaves from various sources that had been stored in silica at ambient temperature were used as initial material for DNA extractions. Approximately $20 \mathrm{mg}$ of leaf dry weight was placed into Lysing Matrix D tubes (MP Biomedicals) and homogenized for $20 \mathrm{~s}$ in MP Fast Prep-24 Buffer PL1. RNaseA obtained from NucleoSpin ${ }^{\circledR}$ Plant II kit (Macherey Nagel USA, Bethlehem, PA) was then added to each tube following recommended volumes and the mixture was homogenized for an additional $20 \mathrm{~s}$. The contents of each tube were then centrifuged and transferred to a NucleoSpin ${ }^{\circledR}$ filter placed in a collection tube and purified using NucleoSpin ${ }^{\circledR}$ Plant II following the manufacturer's recommendations. DNA yields were 5.3 to $347 \mathrm{ng} \cdot \mu \mathrm{L}^{-1}$ in a total volume of $\approx 50 \mu \mathrm{L}$.

Primer design. Anthurium chloroplast gene marker primers were adapted from the Lemna minor chloroplast DNA barcode primer sequence (Wang et al., 2010) and target Anthurium polymerase chain reaction (PCR) product lengths estimated using sequences obtained from high-throughput sequencing of chloroplast-enriched DNA from 
Table 1. Anthurium species chloroplast gene marker primers adapted from Lemna minor chloroplast DNA barcode primer sequences (Wang et al., 2010) based on A. andraeanum Hort. 'New Pahoa Red' chloroplast DNA sequences. ${ }^{\text {' }}$

\begin{tabular}{|c|c|c|c|c|c|c|}
\hline $\begin{array}{l}\text { Target } \\
\text { gene regions }\end{array}$ & $\begin{array}{l}\text { Lemna minor } \\
\text { amplicon (bp) }\end{array}$ & $\begin{array}{c}\text { Anthurium } \\
\text { andraeanum } \\
\text { amplicon (bp) }\end{array}$ & Primers & Primer sequence & $\begin{array}{l}\text { Primer } \\
\text { length }\end{array}$ & $\begin{array}{l}\text { Primer } \\
\mathrm{T}_{\mathrm{m}}\end{array}$ \\
\hline \multirow[t]{2}{*}{ trnH-psbA } & 300 & 335 & *Aa.trnH-psbA.F & 5'-GTGATGCATGAACGTAATGCTC-3' & 22 & 60.8 \\
\hline & & & Lm.trnH-psbA.F & 5'-GTTATGCACGAACGTAATGCTC-3' & & \\
\hline \multirow[t]{2}{*}{ rров } & 406 & 426 & LmAa.rpoB.F & 5'-ATGCAGCGTCAAGCAGTTCCGTTCC-3' & 25 & 67.9 \\
\hline & & & LmAa.rpoB.R & 5'-TCGGATGTGAAAAGAAGTATA-3' & 21 & 54.8 \\
\hline rpoC1 & 509 & 529 & *Aa.rpoC1.F & 5'-GGCAAAGAGGGAAGATTCCG-3' & 20 & 62.4 \\
\hline \multirow[t]{3}{*}{$p s b K-p s b I$} & 544 & 541 & *Aa.psbK-psbI.F & 5'-TTAGCCTTTGTTTGGCAAG-3' & 19 & 55.8 \\
\hline & & & Lm.psbK-psbI.F & 5'-TTAGCATTTGTTTGGCAAG-3' & & \\
\hline & & & LmAa.psbK-psbI.R & 5'-AAAGTTTGAGAGTAAGCAT-3' & 19 & 51.5 \\
\hline \multirow[t]{4}{*}{$r b c L$} & 580 & 599 & *Aa.rbcL.F & 5'-GTAAAATCAAGTCCACCGCG-3' & 20 & 60.4 \\
\hline & & & Lm.rbcL.F & $5^{\prime}$-GTAAAATCAAGTCCACCACG-3'; & & \\
\hline & & & *Aa.rbcL.R & 5'-ATGTCACCACAAACAGAAACTAAAGC-3' & 26 & 61.4 \\
\hline & & & Lm.rbcL.R & 5'-ATGTCACCACAAACAGAGACTAAAGC-3' & & \\
\hline matK & & & Lm.matK.R & 5'-ATCCGGTCCATCTAGAAATATTGGTTC-3' & & \\
\hline
\end{tabular}

${ }^{2}$ DNA bases shown in bold denote base pairs that differ between Anthurium (*Aa.xx) and L. minor (Lm.xx) primers; LmAa.xx denotes primer sequences identical at the corresponding target gene regions of $L$. minor and A. andraeanum. Primer $\mathrm{T}_{\mathrm{m}}$ was based on a general formula provided by the manufacturer (see "Materials and Methods").

A. andraeanum Hort. 'New Pahoa Red' (Suzuki, unpublished data). Primers were obtained from Eurofins, MWG/Operon (Huntsville, AL) with primer $\mathrm{T}_{\mathrm{m}}$ values based on the formula $\left[\mathrm{T}_{\mathrm{m}}=81.5+16.6 \times\right.$ $\log (0.1)+41 \times(\mathrm{G}+\mathrm{C}) /$ length $-500 /$ length] provided by the manufacturer. Of the various target genes, rpoB, rpoC1, rbcL, and

Received for publication 30 Sept. 2013. Accepted for publication 6 Aug. 2014.

We thank Davin J. Vicente for his excellent technical assistance, Barbara J. Bliss for assistance in plant material acquisition, preservation, and documentation, Stephen Wakefield for assistance in herbarium maintenance and inventory, and Dr. Monica Carlsen for generous help in proper sectional placement of Anthurium species. Many thanks to Lynne Kuwabara and the Hawaiian Anthurium Industry Association (HAIA) for providing the Hawaiian anthurium cultivar sample. We express our appreciation to the following persons and institutions for generously providing accessioned plant materials used in this study: Michael Wenzel of Atlantic Botanical Garden (ABG), Jon Peter of New York Botanical Garden (NYBG), Bruce Holst and Laurie Birch of the Marie Selby Botanic Garden (MSBG), Kyle Wallick of the U.S. Botanic Garden (USBG), David Scherberich of Jardin Botanique de la Ville de Lyon (JBVL), Renée Gaudette of Jardin Botanique de Montréal (JBM), Geneviève Ferry of Conservatoire et Jardins Botaniques de Nancy (CJBN), Thomas Croat of the Missouri Botanical Garden (MBG), and Wilhelmina Wasik, Alan Meerow, and Tomas Ayala-Silva of the U.S. Department of Agriculture, Agriculture Research Service, Subtropical Horticulture Research Station, National Clonal Germplasm Repository (USDA ARS SHRS NCGR). Special thank you to Claudia Henriquez, Washington University in St. Louis, for selecting, collecting, packaging, and shipping material from MBG.

${ }^{1}$ To whom reprint requests should be addressed; e-mail jon.suzuki@ars.usda.gov. mat $K$ are coding genes, encoding the beta and N-terminus of the beta's subunit, respectively, of the plastid RNA polymerase, the large subunit RuBisCO and maturase K, respectively. The remaining marker gene sites trnH-psbA, atpF-atpH, and $p s b K-p s b I$ are intervening sequences between the transfer RNA H and photosystem II, D1 protein gene, adenosine- $5^{\prime}$-triphosphate synthase subunit genes, and photosystem II reaction center protein genes, respectively.

Polymerase chain reaction amplification of DNA marker regions for Anthurium species. PCR reactions consisted of $25 \mu \mathrm{L}$ $1 \times$ GoTaq Hot Start Master mix (Promega Corp., Madison, WI), $1 \mu \mathrm{M}$ each of forward and reverse gene primers, and $1 \mu \mathrm{L}$ of extracted DNA. Reactions were carried out by incubation at $94{ }^{\circ} \mathrm{C}$ for 5 min followed by 35 cycles of $94{ }^{\circ} \mathrm{C}$ for $30 \mathrm{~s}, 50{ }^{\circ} \mathrm{C}$ for $30 \mathrm{~s}$, $72{ }^{\circ} \mathrm{C}$ for $40 \mathrm{~s}$, and a final extension of $72{ }^{\circ} \mathrm{C}$ for $5 \mathrm{~min}$. PCR products were run in $2.0 \%$ agarose- $1 \times$ Tris Borate EDTA gels containing $1 \times$ GelRed Nucleic Acid Stain (Phenix Research Products, Candler, NC). Trackit ${ }^{\mathrm{TM}} 1.0 \mathrm{~Kb}$ Plus DNA ladder (Life Technologies, Carlsbad, CA) was used as a molecular weight marker.

\section{Results and Discussion}

Polymerase chain reaction (PCR) primers specific to Anthurium were obtained by comparing primers previously designed for Lemna with a corresponding DNA sequence of the chloroplast genome of Anthurium andraeanum Hort. 'New Pahoa Red', a popular red-spathed Hawaiian cut flower. Anthurium 'New Pahoa Red' chloroplast DNA sequence obtained from high-throughput sequencing of chloroplast-enriched DNA from this cultivar enabled the design of Anthurium-specific primers and prediction of target amplicon sizes (Table 1). PCR primer sequences for $r p o B$ and $a t p F-a t p H$ were unchanged between Lemna and Anthurium, whereas sequence differences were found between target Lemna and Anthurium that warranted base changes in at least one primer of the primer pairs for $r p o C 1$, trn $H$ - $p s b A$, and $p s b K-p s b I$, and differences in both primers of a primer pair found for $r b c L$ and $m a t K$ (Table 1). This result suggests that primer target sites for $r p o B$ and atpF-atpH are more conserved between Lemna and Anthurium compared with those of the other gene sequences examined. The Lemna and Anthurium matK primers contained the most differences from among the primer pairs studied here, a finding that is in line with the observation that $m a t K$ is one of the most variable coding genes in the chloroplast of Angiosperms (Hilu et al., 2003). Predicted amplicon sizes of the Anthurium marker gene matched the relative size order of the corresponding target amplicons of Lemna minor.

DNA was extracted from dried leaves of species representing 14 sections and two clades of the currently recognized 18 subgeneric sections of Anthurium (Croat and Sheffer, 1983) and additional newly recognized clades (Carlsen, 2011; Carlsen and Croat, 2013) (Table 2). Although Anthurium leaves were stored for greater than 2 years on silica at ambient temperature, with a few exceptions, relatively pure DNA as judged by spectrophotometric values $\left(\mathrm{OD}_{260 / 280} \approx 1.8\right)$ was obtained using a commercial plant DNA isolation kit. However, DNA yield did vary considerably ( 5 to $347 \mathrm{ng} \cdot \mu \mathrm{L}^{-1}$ ), which we attribute to differences in the physical properties of the leaves that might have affected proper tissue preservation at the initial stages of the silica drying process and/or parameters affecting DNA extraction and quality such as 
Table 2. Anthurium species used for chloroplast gene marker primer testing in this study. ${ }^{\mathrm{z}}$

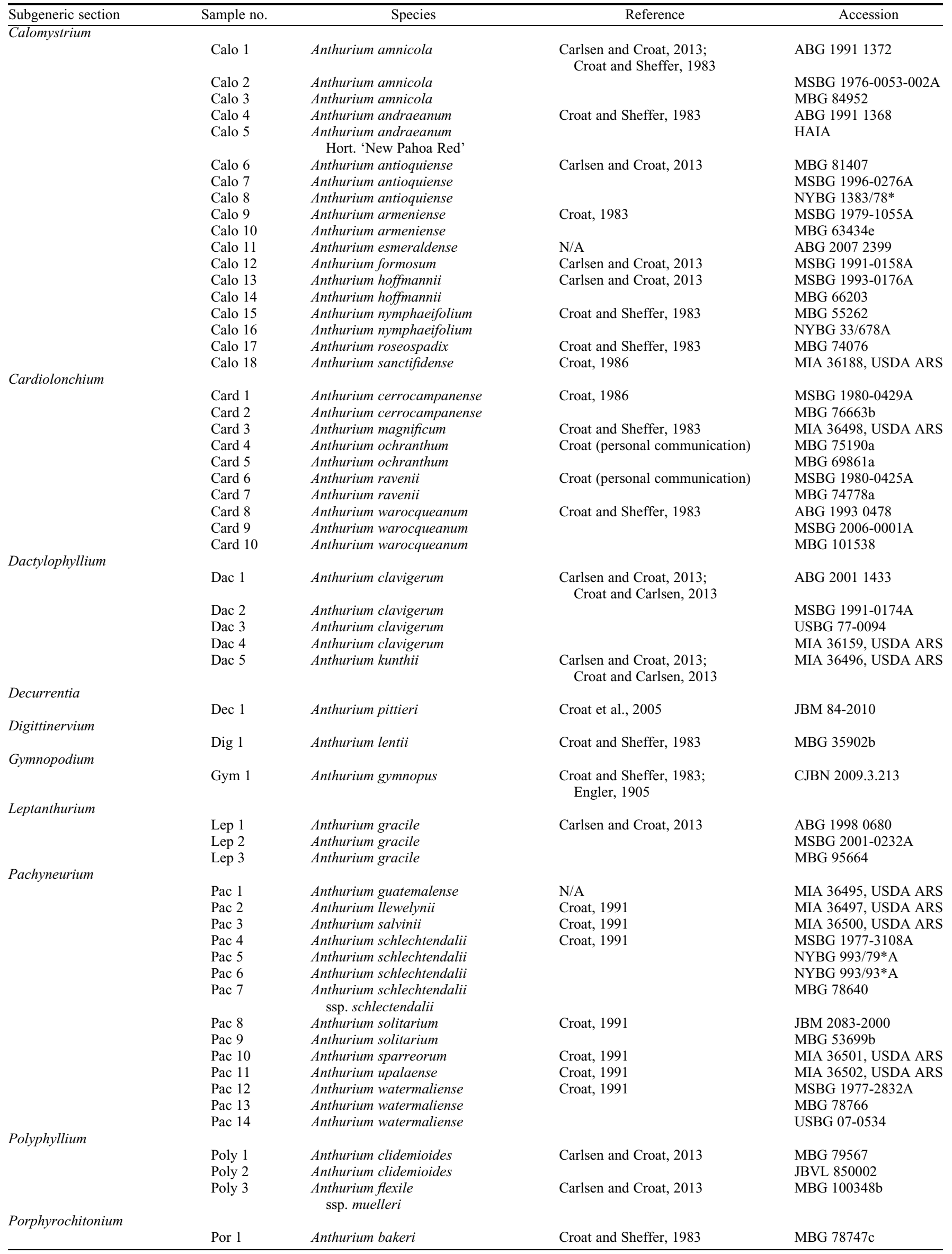


Table 2. (Continued) Anthurium species used for chloroplast gene marker primer testing in this study. ${ }^{\mathrm{z}}$

\begin{tabular}{|c|c|c|c|c|}
\hline$\overline{\text { Subgeneric section }}$ & Sample no. & Species & Reference & Accession \\
\hline & Por 2 & Anthurium bakeri & & NYBG $897 / 63^{*}$ \\
\hline & Por 3 & Anthurium bakeri & & USBG 77-0090 \\
\hline & Por 4 & Anthurium durandii & Croat, 1983 & MIA 36182, USDA ARS \\
\hline & Por 5 & Anthurium fragrantissimum & Croat, 1986 & MBG 76860 \\
\hline & Por 6 & Anthurium wendlingerii & Croat and Sheffer, 1983 & ABG 20072507 \\
\hline & Por 7 & Anthurium wendlingerii & & MSBG 1977-1989A \\
\hline & Por 8 & Anthurium wendlingerii & & MBG 95418 \\
\hline & Por 9 & Anthurium wendlingerii & & USBG 01-1412 \\
\hline \multicolumn{5}{|l|}{ Semaeophyllium } \\
\hline & Sem 1 & Anthurium trilobum & Carlsen and Croat, 2007 & MIA 36184 , USDA ARS \\
\hline \multicolumn{5}{|l|}{ Tetraspermium } \\
\hline & Tet 1 & Anthurium obtusum & Carlsen and Croat, 2013 & ABG 19970478 \\
\hline & Tet 2 & Anthurium obtusum & & MBG 82905 \\
\hline & Tet 3 & Anthurium scandens ssp. pusillum & & ABG 19980667 \\
\hline & Tet 4 & Anthurium scandens ssp. pusillum & & USBG 98-1900 \\
\hline & Tet 5 & Anthurium scandens ssp. scandens & Carlsen and Croat, 2013 & ABG 19911433 \\
\hline & Tet 6 & Anthurium scandens ssp. scandens & & MBG 47671 \\
\hline \multicolumn{5}{|l|}{ Urospadix } \\
\hline & Uro 1 & Anthurium coriaceum & Carlsen and Croat, 2013 & NYBG $574 / 65^{*} \mathrm{~A}$ \\
\hline & Uro 2 & Anthurium coriaceum & & USBG 98-1747 \\
\hline & Uro 3 & Anthurium radicans & Carlsen and Croat, 2013 & ABG 19911495 \\
\hline & Uro 4 & Anthurium radicans & & MSBG 1975-0053-003A \\
\hline & Uro 5 & Anthurium radicans & & USBG 98-2591 \\
\hline \multicolumn{5}{|l|}{ Xialophyllium } \\
\hline & Xia 1 & Anthurium microspadix & Croat and Sheffer, 1983 & MBG 100186 \\
\hline \multicolumn{5}{|l|}{ Other classifications } \\
\hline Mexican Epunctate clade & ME 1 & Anthurium leuconeurum & Carlsen and Croat, 2013 & MSBG 1980-1683B \\
\hline Mexican Epunctate clade & ME 2 & Anthurium pedatoradiatum & Carlsen and Croat, 2013 & MIA 36499 , USDA ARS \\
\hline Mexican Punctate clade & MP 1 & Anthurium lucens & Carlsen and Croat, 2013 & MSBG 1980-1619A \\
\hline Mexican Punctate clade & MP 2 & Anthurium lucens & & MBG 78702 \\
\hline Mexican Punctate clade & MP 3 & Anthurium lucens & & NYBG $103 / 81 *$ \\
\hline
\end{tabular}

${ }^{2}$ Accessioned dried leaf tissue samples were obtained from Atlanta Botanical Garden (ABG), Conservatoire et Jardins Botaniques de Nancy (CJBN), Hawaii Anthurium Industry Association (HAIA), Jardin Botanique de Montréal (JBM), Jardin Botanique de la Ville de Lyon (JBVL), Marie Selby Botanical Gardens (MSBG), Missouri Botanical Garden (MBG), New York Botanical Garden (NYBG), U.S. Botanic Garden (USBG), U.S. Department of Agriculture, Agriculture Research Service, Subtropical Horticulture Research Station, National Clonal Germplasm Repository (USDA ARS SHRS NCGR or USDA ARS).

$\mathrm{N} / \mathrm{A}=$ original reference not available.

tissue maceration efficiency and presence of secondary compounds.

Extracted DNA of species from the section Calomystrium was chosen as a small sample set to test for PCR template quality and the efficiency of the various primers to amplify the target gene fragments studied here. These species were chosen for initial tests, because a large majority of the commercial hybrids of Anthurium derive from crosses between species in section Calomystrium, and we have ongoing interest in developing approaches for delineating their similarities and differences at the molecular level. Moreover, it would be predicted that the target chloroplast sequences of species sampled in this section would likely be conserved with corresponding sequences of $A$. andraeanum Hort. 'New Pahoa Red', a member species of section Calomystrium.

Previously, the trnH-psbA region was used for molecular systematic studies across a large number of widely related Anthurium species to reconstruct the molecular phylogeny of the genus (Carlsen, 2011; Carlsen and Croat, 2013) and the PCR primers designed in our study for this marker gene also resulted in efficient amplification from both the New Pahoa Red cultivar as well as other species in section Calomystrium (Table 2; Fig. 1A). In general, other PCR primer pairs tested were efficient in amplifying amplicons of expected size across species tested in this subgeneric Anthurium group (Fig. 1A-G) with amplicons close to the predicted marker gene amplicon size for 'New Pahoa Red' chloroplast DNA sequence (Table 1) based on migration in agarose gels relative to DNA molecular weight marker bands: trnH-psbA (300 to $400 \mathrm{bp}$ ), rpoB (400 to $500 \mathrm{bp})$, rpoC1 (500 to $650 \mathrm{bp}$ ), psbK-psbI (500 to $650 \mathrm{bp}$ ), $r b c L$ (500 to $650 \mathrm{bp}$ ), $\operatorname{atpF-atpH}$ (650 to $850 \mathrm{bp}$ ), and $\operatorname{matK}(850$ to $1000 \mathrm{bp}$ ) (Fig. $1 \mathrm{~A}-\mathrm{G}$ ). Amplicons were not visible in PCR reactions containing the samples 'Calo 8, 9, and 15' (accessions representing $A$. antioquiense, $A$. armeniense, and A. nymphaeifolium), primers for atpF-atpH and 'Calo 9 and 15' using primers for matK, not readily visible for samples 'Calo 2' and 'Calo 7', primers for atpF-atpH representing one of three accessions of $A$. amnicola, and a second of three accessions of $A$. antioquiense. For samples 'Calo 9' and 'Calo 15' with DNAs OD $260 / 280$ 1.45 or less and calculated DNA concentrations of 41.9 and $35.3 \mathrm{ng} \cdot \mu \mathrm{L}^{-1}$, respectively, low or no amplification was likely as a result of suboptimal DNA template quality because similar lower amplification efficiency was observed for these samples using other primer sets. These results demonstrate that the PCR primers were effective in amplifying the target gene amplicons from DNA of different Anthurium species and, in addition, the tissue storage and DNA extraction methods used were in general effective methods to obtain amplifiable DNA for this application.
According to Wang and collaborators (Wang et al., 2010), PCR products from the coding genes $r p o B, r p o C 1, r b c L$, and mat $K$ were identical in product length across the 31 species tested from the subfamily Lemnaceae, whereas the intergenic sites trnH-psbA, psbK-psbI, and atpF-atpH varied considerably in amplicon size as a result of insertions/deletions. The $p s b K-p s b I$ primers exhibited the highest amplification rate among different Lemna species and the most variability between species. Although intraspecies variability was high using $p s b K$-psbI primers, it was less than that of $\operatorname{trnH}$ - $p s b A$, a region that is often variable in length among different species or samples owing to its position at the junction of the chloroplast large single copy sequence and the inverted repeat (Wang et al., 2008). Based on these observations and our goal of identifying visible species markers, we tested primers for intergenic sites trnH-psbA, psbK-psbI, and atpF-atpH with our collection of DNA extracted from various Anthurium species (Table 2). Figure 2A shows $t r n H-p s b A$ amplicons from different species loaded in agarose gels according to subgeneric groupings. Among the different subgeneric groups, amplicons showed significant polymorphism compared with 335 bp predicted for $A$. andraeanum Hort. 'New Pahoa Red', migrating between the 300- and 500-bp DNA molecular weight markers, 


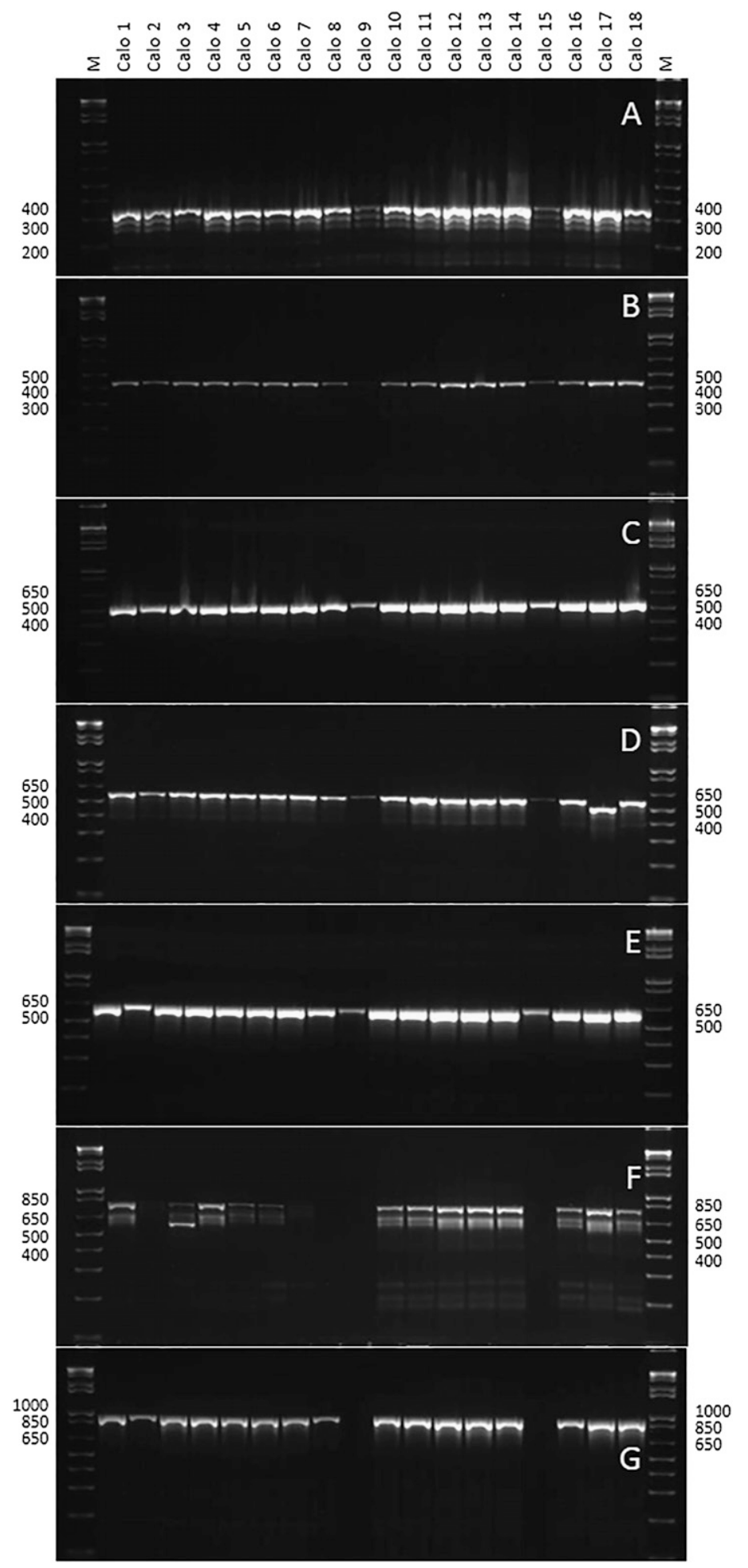

Fig. 1. Agarose gel electrophoresis of polymerase chain reaction (PCR) amplifications of target chloroplast gene marker regions from Anthurium species belonging to subgeneric section Calomystrium. Anthurium species samples are labeled according to Table 2. Anthurium primers used in amplification reactions corresponded to target genes (A) trnH-psbA, (B) $r p o B$, (C) $r p o C 1$, (D) $p s b K-p s b I$, (E) $r b c L$, (F) $a t p F-a t p H$, and (G) $m a t K$. DNA markers.

a size range where amplicon size differences are relatively easily resolved on agarose gels. Interestingly, species in the crown group Polyphyllium apparently have the largest $t r n H-p s b A$ amplicons compared with species in other sections tested. Among sections excluding Decurrentia, Digittinervium,
Intraspecies variation was apparent between accessions of Cardiolonchium species $A$. ravenii (Card 6, 7), Pachyneurium species A. schlechtendalii (Pac 4, 5, 6, 7), and Mexican punctate species $A$. lucens (MP 1, 2, 3 ). Amplicons corresponding to $p s b K-p s b I$ migrated in agarose gels between two main size classes, one consistent with the amplicon predicted for A. andraeanum Hort. (541 bp; Table 1) migrating in agarose gels above the 500-bp marker and a second size class below the 500-bp molecular weight marker (Fig. 2B). Single sample exceptions in amplicon size were observed for $A$. roseospadix (Calo 17) and A. coriaceum (Uro 2) of sections Calomystrium and Urospadix, respectively, whereas greater variation in incidence as well as amplicon size was apparent among species in section Pachyneurium. Intraspecies psbK-psbI amplicon variation was observed for Pachyneurium species, A. schlechtendalii (Pac 4, 5, 6, 7), A. solitarium (Pac 8, 9), and Urospadix section, A. coriaceum (Uro 1,2). The atpF-atpH primer pair amplicon(s) migrated as three or four molecular weight species in agarose gels between 650 to 850 bp with the largest, major band consistent with $750 \mathrm{bp}$ predicted for the amplicon from A. andraeanum Hort. 'New Pahoa Red' (Fig. 2C). In preliminary experiments, increasing the stringency of PCR annealing temperatures of up to $10^{\circ}$ did not substantially alter amplicon patterns for any of the primer pairs tested, suggesting that the smaller extraneous PCR products may result from subsegments of the target sequences. Size variation in the atpF-atpH amplicon(s) were apparent in section Porphyrochitonium between A. bakeri (Por $1,2,3)$ and other species of the section and possible differences between $A$. leuconeurum and $A$. pedatoradiatum of the Mexican epunctate clade. Intraspecies differences between $a t p F$-atpH amplicon(s) were apparent between accessions of $A$. solitarium (Pac $8,9)$ and $A$. schlechtendalii (Pac 4, 5, 6, 7) of section Pachyneurium and accessions of A. gracile (Lep 1,2,3) of section Leptanthurium with little if any other intersectional variation detected at this resolution.

Positive amplification was obtained for $96.4 \%$ of the Anthurium species DNA samples using trnH-psbA or $p s b K-p s b I$ primer pairs and $91.6 \%$ of the Anthurium species DNA samples using atp $F$-atpH primer pairs. Three samples, 'Card 1' (A. cerrocampanense), 'Por 5' (A. fragrantissimum) and 'Tet 2' (A. obtusum), template DNAs had $\mathrm{OD}_{260 / 280} 1.54$ or less and lacked visible PCR amplicons for all chloroplast trnH-psbA, $p s b K$-psbI, and atpF-atpH intergenic site primers suggesting that the lack of amplification might be affected by DNA template quality and amount. This could also be the cause of similar, low or no amplicon amplification for samples 'Calo 9' and 'Calo 15' (A. armeniense and A. nymphaeifolium, respectively) using atpF-atpH (Fig. 2C) and other intergenic site primers (Fig. 1A-G). In the case of 'Calo 8' and 'Card 4' (A. antioquiense and $A$. ochranthum, respectively) with an $\mathrm{OD}_{260 / 280}=1.73$ and a concentration 
A
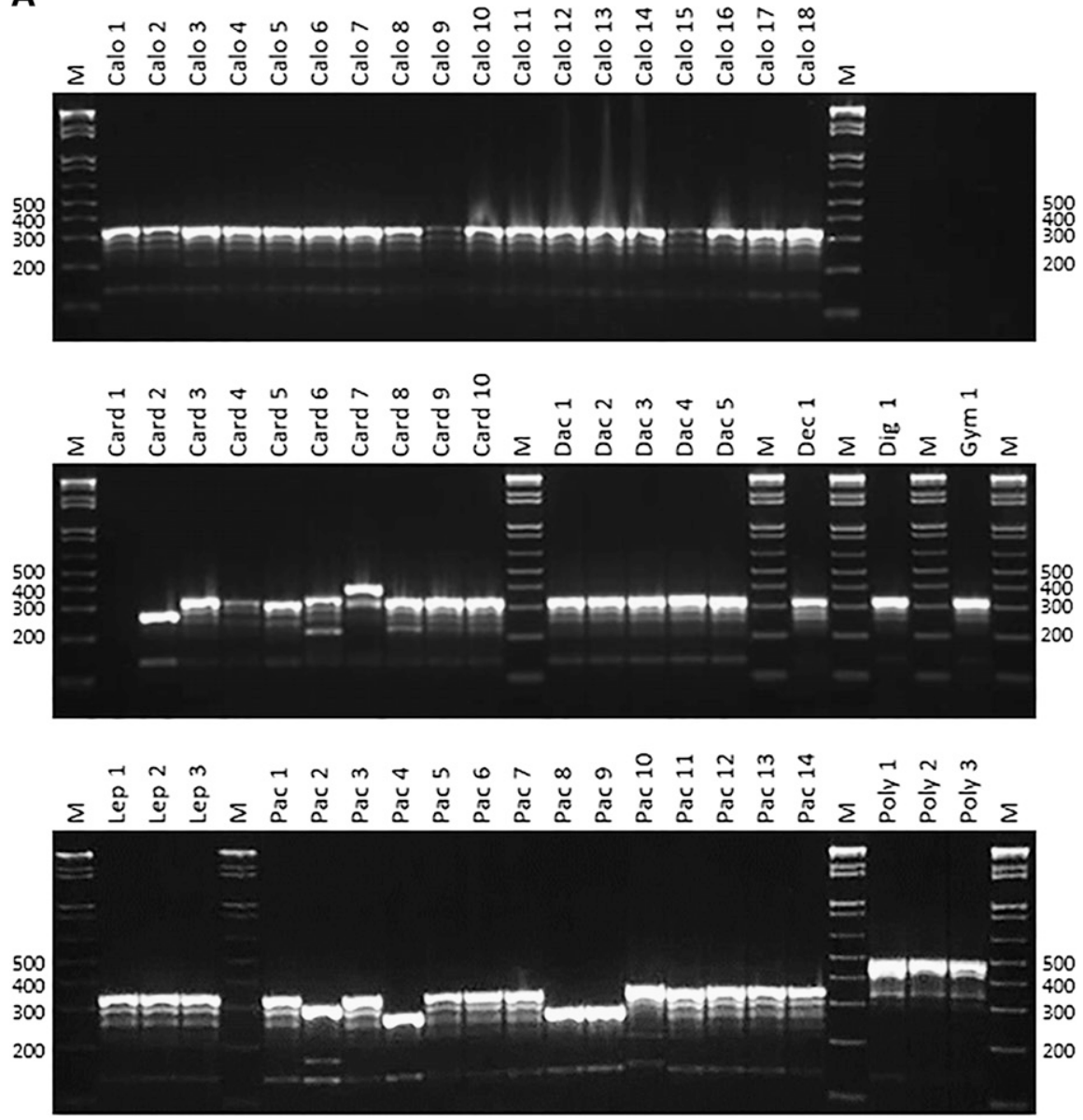

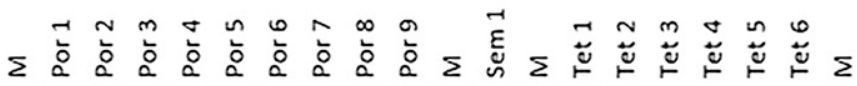

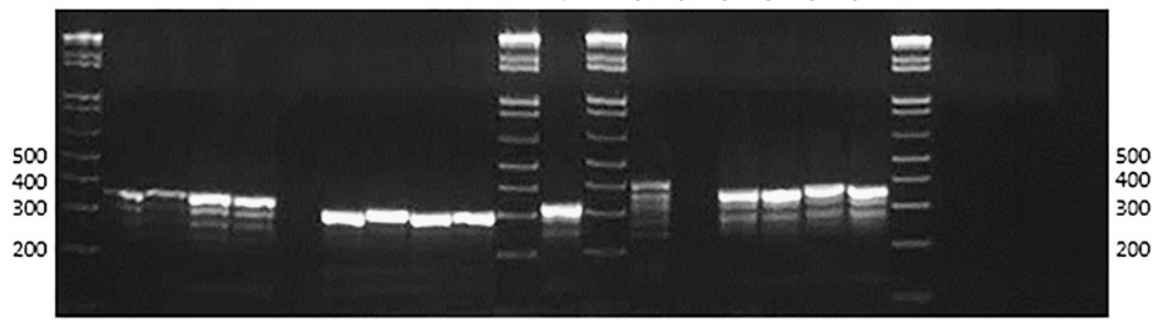

$\rightarrow \sim m \rightarrow n \rightarrow N m$

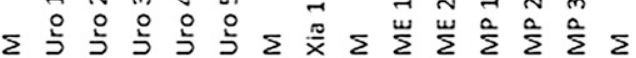

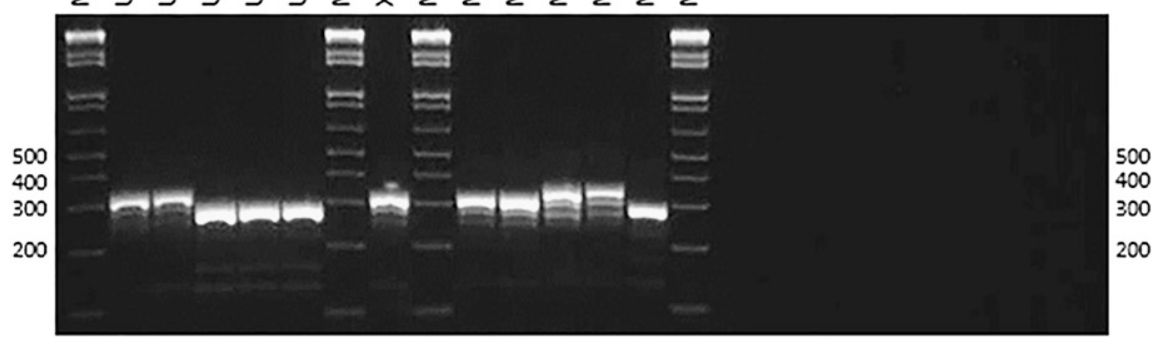

Fig. 2. Agarose gel electrophoresis of polymerase chain reaction (PCR) amplified target chloroplast sequence amplicons from Anthurium species loaded according to subgeneric grouping. (A) trnH-psbA amplicons, (B) $p s b K$-psbI amplicons, (C) atpF-atpH amplicons. DNA markers (lane $\mathrm{M}$ ) are labeled at relevant positions with corresponding molecular weight in base pairs.

greater than $22 \mathrm{ng} \cdot \mu \mathrm{L}^{-1}$, low or no PCR product obtained with the atpF-atpH primer might also be attributable in part to primer design because similar results were observed in at least one other accession of $A$. antioquiense
('Calo 7') and A. ochranthum ('Card 5') using the same primers.

Of the three chloroplast intergenic sites examined, $p s b K-p s b I$ varied sufficiently to differentiate distinct species on agarose gels compared with atpF-atpH and appeared to exhibit less intraspecific and intrasectional differences as compared with trnH-psbA. Of the two major psbK-psbI amplicon size classes observed, sections heavily represented by the larger $p s b K-p s b I$ amplicon size class were Cardiolonchium, Calomystrium, and the Mexican epunctate clade represented by the species $A$. leuconeurum and $A$. pedatoradiatum as well as Urospadix and the earliest diverging lineage represented by the section Polyphyllium, according to the molecular phylogenies by Carlsen (Carlsen, 2011; Carlsen and Croat, 2013) (Fig. 2B). By contrast, sections heavily represented by species with the smaller $p s b K-p s b I$ amplicon included Porphyrochitonium, Tetraspermium, Pachyneurium, Leptanthurium, Dactylophyllium, and the Mexican punctate clade represented by $A$. lucens, sections that appear to also cluster closer together phylogenetically (Carlsen, 2011; Carlsen and Croat, 2013). Despite heterogeneity in $p s b K-p s b I$ amplicon size in certain tested Anthurium sections, the intraspecies variation observed in Lemna (Wang et al., 2010) and in Anthurium (this study), in addition to the monophyly of certain sections still being questioned and re-evaluated (Carlsen, 2011), this study shows the potential use of the $p s b K-p s b I$ intergenic region for genotyping broad sectional relationships among species within Anthurium. Increasing the number of species and accessions sampled from the various Anthurium sections along with continued refinement of molecular phylogenetic classifications should enable further assessment of $p s b K-p s b I$ amplicon size patterns among sectional groups. Increased sampling as well as reverification of source material should in addition aid in vetting errors in taxonomic identification of samples that might be the origin of peculiar results found in this and future studies.

In this study, we examined a new set of gene markers that were previously used successfully in Lemna to resolve interspecies relationships based on DNA sequence comparisons. The $p s b K-p s b I$ chloroplast gene region DNA sequence has also been used for species identification of various plants that are more distantly related to Anthurium (Lahaye et al., 2008), but to our knowledge has not been systematically examined at any level, DNA sequence, or amplicon size among species in this genus.

According to Carlsen (Carlsen, 2011; Carlsen and Croat, 2013), there is low-sequence divergence among Anthurium species for the chloroplast markers they used; she found that inclusion of the CHS nuclear gene intron in her molecular phylogenetic analyses better resolved monophyletic groups among Anthurium species as compared with the use of chloroplast gene markers alone (Carlsen, 2011; Carlsen and Croat, 2013). Nevertheless, chloroplast marker genes have been used to trace lineage in orchids (Khew and Chia, 2011; Tsai et al., 2012) and species or lineage-specific regions of the chloroplast genome have been identified from comparative analyses of related orchid genomes (Jheng 
B
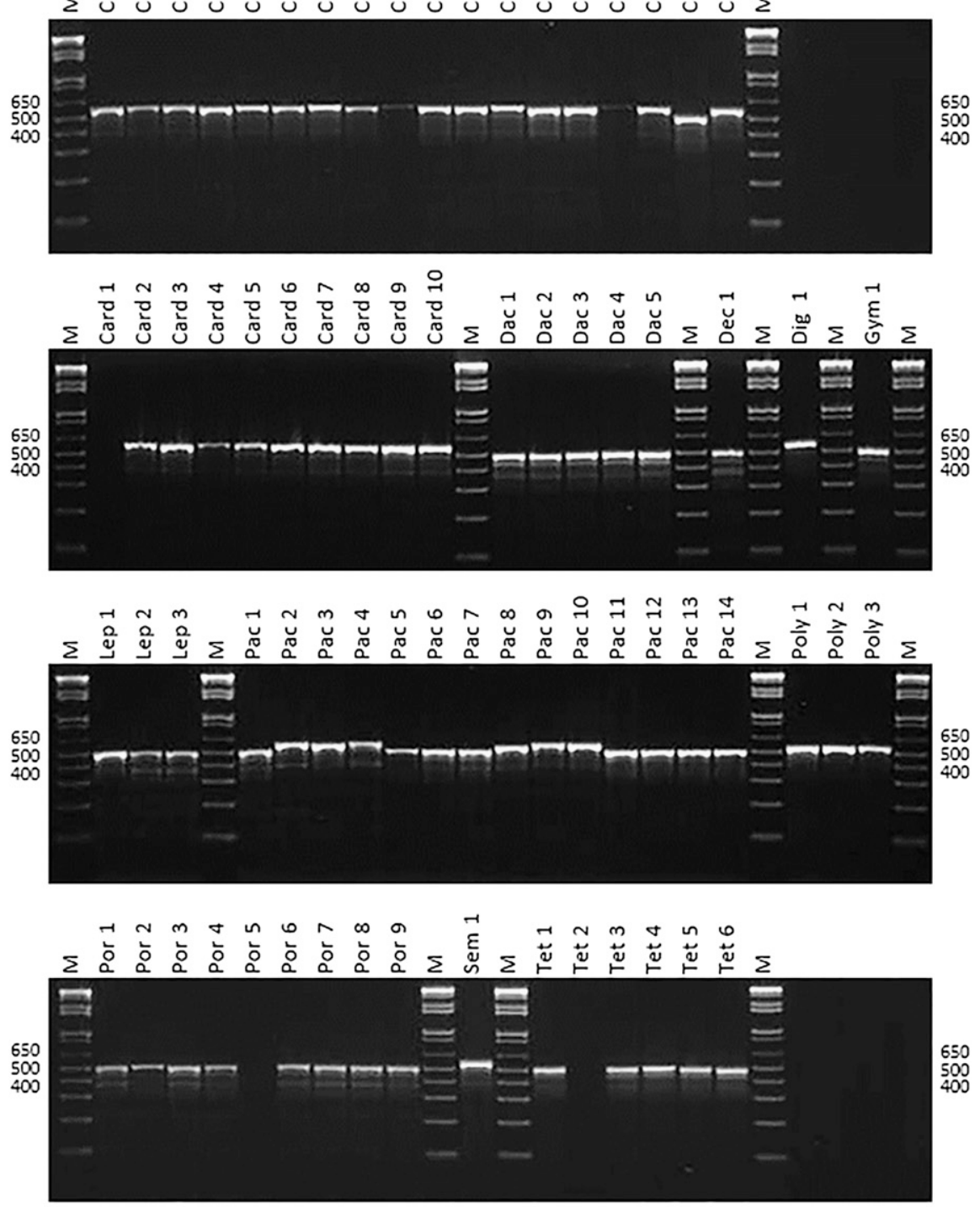

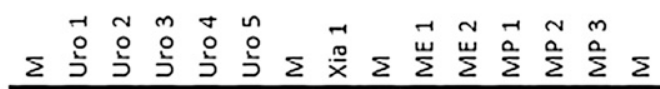

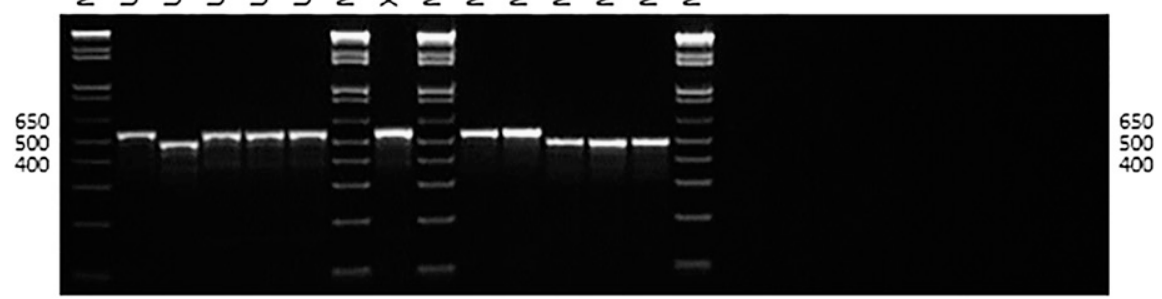

Fig. 2. (Continued)

et al., 2012; Pan et al., 2012; Wu et al., 2010; Yang et al., 2013) to support breeding and ornamental improvement. In the study by Jheng and collaborators, gene markers were developed from the variable regions revealed by comparisons of whole genomes that could identify individual species by differences in PCR amplicon size (Jheng et al., 2012). This tool would be similarly useful in Anthurium, for example, in the evaluation of Anthurium pedigrees derived from interspecific crosses.

Rapid advances in chloroplast sequencing methodology (Atherton et al., 2010; Cronn et al., 20008, 2012; Moore et al., 2006; Nock et al., 2011; Parks et al., 2009; Stull et al., 2013) should increase the number of whole chloroplast genomes available for Anthurium thereby increasing chloroplast genome information available for Araceae (Ahmed et al., 2012; Mardanov et al., 2008; Wang and Messing, 2011). Sequencing of chloroplast genomes should allow identification of sites that provide higher phylogenetic resolution at lower taxonomic levels in Anthurium as well as aid in identification of species-specific markers most appropriate for diagnostic genotyping of germplasm in this genus. Like in the case of Lemna, gene markers useful for barcoding and species identification (Wang et al., 2010) need not necessarily be the same genes useful for resolving molecular phylogenetic relationships (Les et al., 2002). Improvements to the resolving power of the genotyping method could be made by multiplexing marker genes and the use of separation systems such as those used for amplified fragment length polymorphism analyses (Karudapuram and Larson, 2005) that enable high amplicon size resolution of large amplicon populations.

Development of simple genotyping markers or its approaches should complement more complex techniques developed to identify or characterize different cultivars or closely related species comprising commercial Anthurium germplasm (Bliss and Suzuki, 2012; Buldewo et al., 2012; Collette et al., 2004; Ge et al., 2012; Khan and Pankajaksan, 2010; Nowbuth et al., 2005; Ranamukhaarachchi et al., 2001; Wang and Chuang, 2013; Wang et al., 2013; Yu et al., 2012) to support improvement of ornamental and horticultural traits of Anthurium.

Finally, as demonstrated in this study, the availability of a tissue bank was invaluable as a genetic reference resource for testing hypotheses and for a comparative analysis of genes across Anthurium species. Dried leaf collections can be kept for relatively long periods without expensive facilities and although Anthurium is known to contain polysaccharides that inhibit PCR (Buldewo and Jaufeerally-Fakim, 2002), the commercially available plant column purification procedure used in this study yielded in most cases DNA template of sufficient quality and quantity.

\section{Literature Cited}

Ahmed, I., P.J. Biggs, P.J. Matthews, L.J. Collins, M.D. Hendy, and P.J. Lockhart. 2012. Mutational dynamics of aroid chloroplast genomes. Genome Biol. Evol. 4:1316-1323.

Atherton, R., B. McComish, L. Shepherd, L. Berry, N. Albert, and P. Lockhart. 2010. Whole genome sequencing of enriched chloroplast DNA using the Illumina GAII platform. Plant Methods 6:22

Bliss, B.J. and J.Y. Suzuki. 2012. Genome size in Anthurium evaluated in the context of karyotypes and phenotypes. AoB Plants 2012:pls006. doi: 10.1093/aobpla/pls006. <http://aobpla oxfordjournals.org/content/2012/pls006.abstract $>$.

Boyce, P.C. and T.B. Croat. 2012. The Überlist of Araceae: Totals for published and estimated number of species in aroid genera. 27 Feb. 2014. <http://www.aroid.org/genera/ 120110uberlist.pdf $>$.

Buldewo, S. and Y.F. Jaufeerally-Fakim. 2002. Isolation of clean and PCR-amplifiable DNA from Anthurium andraeanum. Plant Mol. Biol. Rpt. 20:71.

Buldewo, S., M. Pillay, and Y. Jaufeerally-Fakim. 2012. Genetic diversity in Anthurium andraeanum cultivars in Mauritius. Afr. J. Biotechnol. 11:16737-16744.

Carlsen, M. and T.B. Croat. 2007. Taxonomic revision of Anthurium section Semaeophyllium Schott (Araceae). Harv. Pap. Bot. 12:173-234. 
C

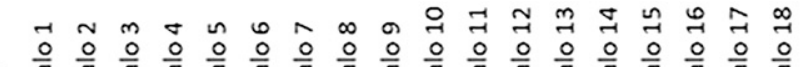

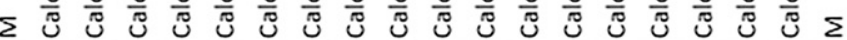
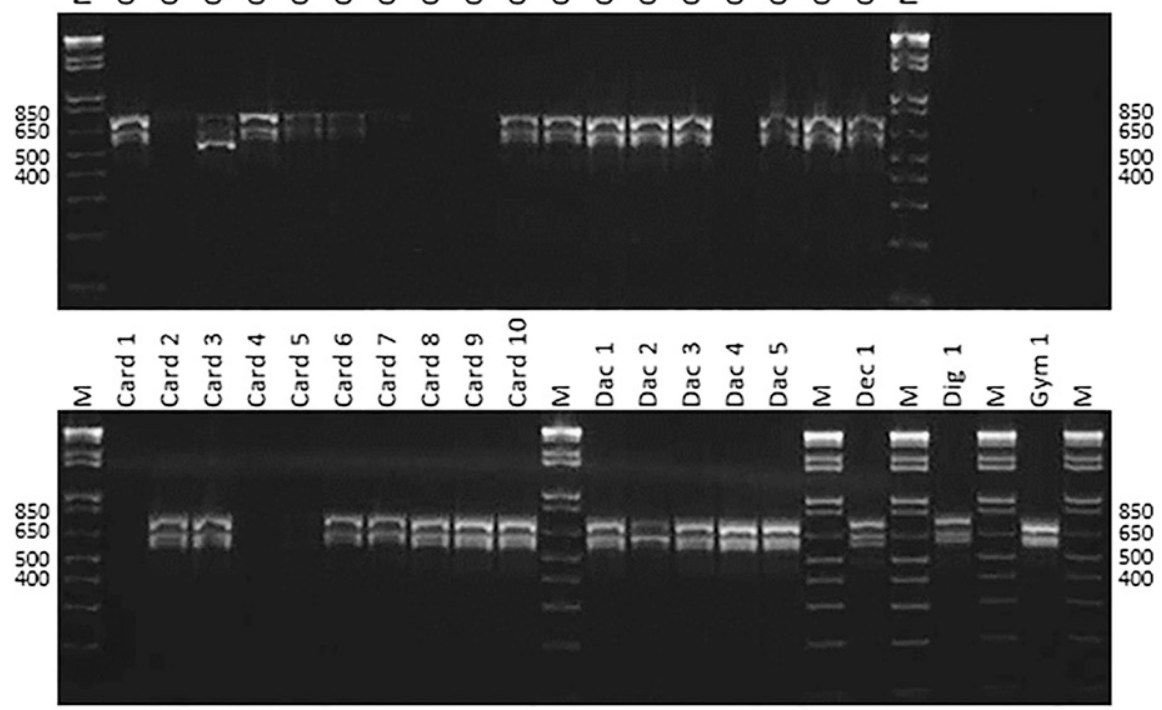

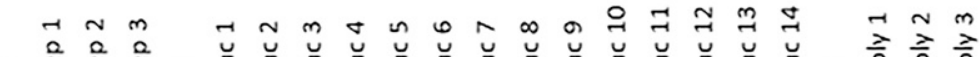

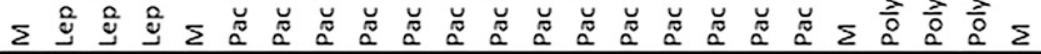

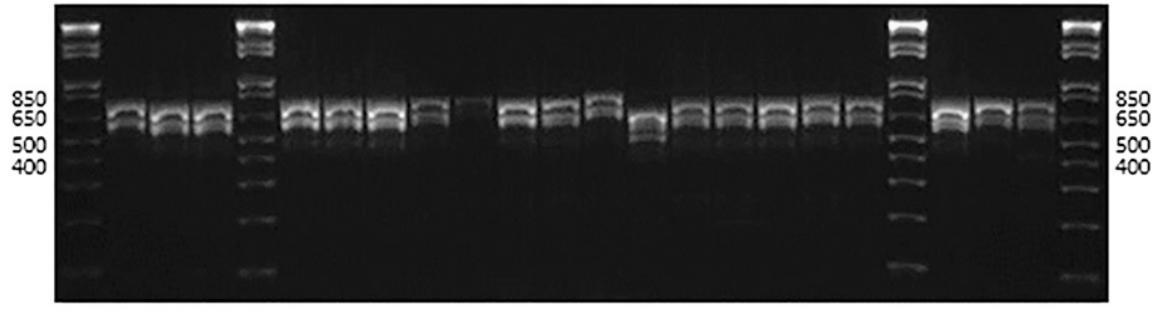

$\Sigma$ 范

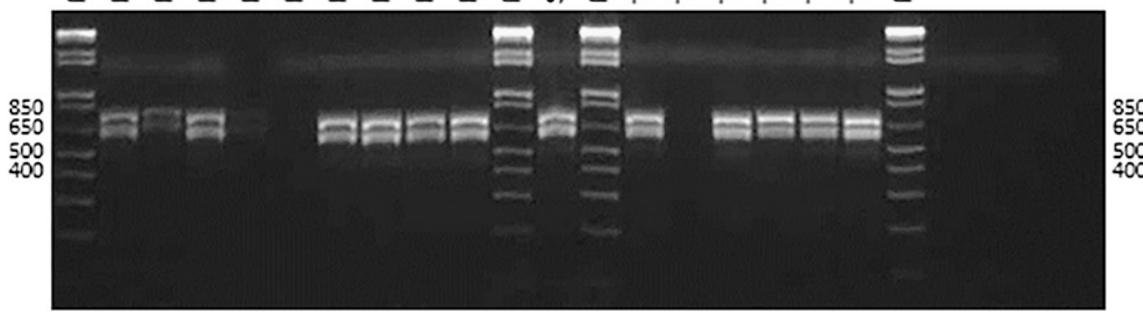

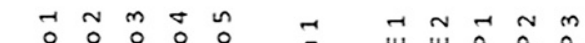

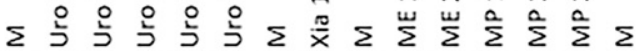

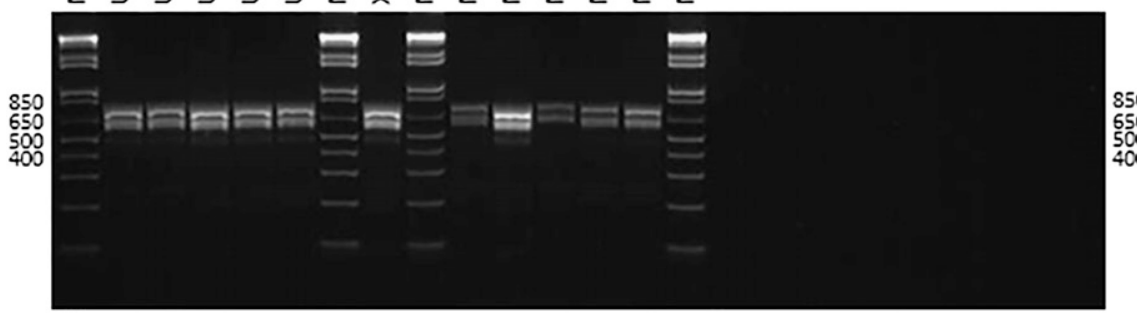

Fig. 2. (Continued)

Carlsen, M.M. 2011. Understanding the origin and rapid diversification of the genus Anthurium Schott (Araceae), integrating molecular phylogenetics, morphology and fossils. PhD diss., University of Missouri-St. Louis, St. Louis, MO.

Carlsen, M.M. and T.B. Croat. 2013. A molecular phylogeny of the species-rich neotropical genus Anthurium (Araceae) based on combined chloroplast and nuclear DNA. Syst. Bot. 38:576-588.
CBOL Plant Working Group. 2009. A DNA barcode for land plants. Proc. Natl. Acad. Sci. USA 106:12794-12797.

Collette, V.E., P.E. Jameson, K.E. Schwinn, P. Umaharan, and K.M. Davies. 2004. Temporal and spatial expression of flavonoid biosynthetic genes in flowers of Anthurium andraeanum. Physiol. Plant. 122:297-304.

Croat, T.B. 1983. A revision of the genus Anthurium (Araceae) of Mexico and Central America.
Part I: Mexico and Middle America. Ann Missouri Bot. Gard. 70:211-420.

Croat, T.B. 1986. Monographs in systematic botany from the Missouri Botanical Garden. 14:98101, f. $81-82$.

Croat, T.B. 1991. A revision of Anthurium section Pachyneurium (Araceae). Ann. Mo. Bot. Gard. 78:539-855.

Croat, T.B. and R.S. Sheffer. 1983. The sectional groupings of Anthurium (Araceae). Aroideana 6:85-123.

Croat, T.B. and M.M. Carlsen. 2013. A reassessment of Anthurium species with palmately divided leaves, and a reinterpretation of $A n$ thurium section Dactylophyllium (Araceae). PhytoKeys 23:41-54.

Croat, T.B., J. Língan, and D. Hayworth. 2005. A new section of Anthurium, Sect. DecurrentiaRevision of the Anthurium decurrens Poeppig complex in Amazonia. Rodriguésia 56(88):1530.

Cronn, R., B. Knaus, A. Liston, P. Maughan, M Parks, J. Syring, and J. Udall. 2012. Targeted enrichment strategies for next-generation plant biology. Amer. J. Bot. 99:291-311.

Cronn, R., A. Liston, M. Parks, D. Gernandt, R. Shen, and T. Mockler. 2008. Multiplex sequencing of plant chloroplast genomes using solexa sequencing-by-synthesis technology. Nucleic Acids Res. 36:19.

Engler, A. 1905. Araceae-Pothoideae, p. 1-330. In: Engler, A. (ed.). Das Pflanzenreich 214:23B. Wilhelm Engelmann, Leipzig, Germany.

Ge, Y., F. Zhang, X. Shen, Y. Yu, X. Pan, X. Liu, J. Liu, G. Pan, and D. Tian. 2012. Genetic variations within a collection of anthuriums unraveled by morphological traits and AFLP markers. Biochem. Syst. Ecol. 45:34-40.

Govaerts, R.J., J. Bogner, J. Boos, P.C. Boyce, B. Cosgriff, T.B. Croat, E. Gonçalves, M.H. Grayum, A. Hay, W.L.A. Hetterscheid, S. Ittenbach, E. Landolt, S.J. Mayo, J. Murata, V.D. Nguyen, C.M. Sakuragui, Y. Singh, S. Thompson, and G. Zhu. 2014. (ongoing) World checklist of Araceae. The Board of Trustees of the Royal Botanic Gardens, Kew, UK. 24 Feb. 2014. <http://www.kew.org/ $\mathrm{Wcsp} />$.

Hilu, K., T. Borsch, K. Muller, D. Soltis, P Soltis, V. Savolainen, M. Chase, M. Powell, L. Alice, R. Evans, H. Sauquet, C. Neinhuis, T. Slotta, J. Rohwer, C. Campbell, and L. Chatrou. 2003. Angiosperm phylogeny based on $\operatorname{mat} K$ sequence information. Amer. J. Bot. 90:1758-1776.

Jheng, C.-F., T.-C. Chen, J.-Y. Lin, T.-C. Chen, W.-L. Wu, and C.-C. Chang. 2012. The comparative chloroplast genomic analysis of photosynthetic orchids and developing DNA markers to distinguish Phalaenopsis orchids. Plant Sci. 190:62-73.

Kamemoto, H. and A.R. Kuehnle. 1996. Breeding Anthuriums in Hawaii. University of Hawai'i Press, Honolulu, HI.

Karudapuram, S. and S. Larson. 2005. Identification of Hedysarum varieties using amplified fragment length polymorphism on a capillary electrophoresis system. J. Biomol. Tech. 16:318-326.

Khan, Y.J. and M. Pankajaksan. 2010. Genetic diversity among commercial varieties of Anthurium andraeanum Linden using RAPD markers. Journal of Plant Genetics and Transgenics 1:11-15.

Khew, G.S.-W. and T.F. Chia. 2011. Parentage determination of Vanda Miss Joaquim (Orchidaceae) through two chloroplast genes $r b c L$ and matK. AoB Plants 2011: Plr018. doi: 10.1093/ aobpla/plr018. < http://aobpla.oxfordjournals.org/ content $/ 2011 /$ plr018.abstract $>$. 
Lahaye, R., V. Savolainen, S. Duthoit, O. Maurin, and M. van der Bank. 2008. A test of $p s b K-p s b I$ and $a t p F-a t p H$ as potential plant DNA barcodes using the flora of the Kruger National Park (South Africa) as a model system. Nature Proceedings: Hdl:10101/npre.2008.1896.1. <http:// arbol.uniandes.edu.co/Archivos/Lahaye-A test of psbK-psbI and atpF-atpH.pdf>.

Les, D.H., D.J. Crawford, E. Landolt, J.D. Gabel, and R.T. Kimball. 2002. Phylogeny and systematics of Lemnaceae, the Duckweed family. Syst. Bot. 27:221-240.

Mardanov, A., N. Ravin, B. Kuznetsov, T. Samigullin, A. Antonov, T. Kolganova, and K. Skyabin. 2008. Complete sequence of the duckweed (Lemna minor) chloroplast genome: Structural organization and phylogenetic relationships to other angiosperms. J. Mol. Evol. 66:555-564.

Matsumoto, T.K., L.M. Keith, R.Y. Cabos, J.Y. Suzuki, D. Gonsalves, and R. Thilmony. 2013. Screening promoters for Anthurium transformation using transient expression. Plant Cell Rep. 3:443-451.

Moore, M., A. Dhingra, P. Soltis, R. Shaw, W. Farmerie, K. Folta, and D. Soltis. 2006. Rapid and accurate pyrosequencing of angiosperm plastid genomes. BMC Plant Biol. 6:17.

Nock, C.J., D.L.E. Waters, M.A. Edwards, S.G. Bowen, N. Rice, G.M. Cordeiro, and R.J. Henry. 2011. Chloroplast genome sequences from total DNA for plant identification. Plant Biotechnol. J. 9:328-333.

Nowbuth, P., K. Govindranathsing, T. Bahorun, and S. Venkatasamy. 2005. Assessing genetic diversity of some Anthurium andraeanum Hort. cut-flower cultivars using RAPD markers. Afr. J. Biotechnol. 4:1189-1194.

Pan, I.C., D.C. Liao, F.H. Wu, H. Daniell, N.D. Singh, C. Chang, M.C. Shih, M.T. Chan, and C.S. Lin. 2012. Complete chloroplast genome sequence of an orchid model plant candidate: Erycina pusilla apply in tropical Oncidium breeding. PLoS One 7:E34738.
Parks, M., R. Cronn, and A. Liston. 2009. Increasing phylogenetic resolution at low taxonomic levels using massively parallel sequencing of chloroplast genomes. BMC Biol. 7:84.

Ranamukhaarachchi, D.G., R.J. Henny, C.L. Guy, and Q.B. Li. 2001. DNA fingerprinting to identify nine Anthurium pot plant cultivars and examine their genetic relationship. HortScience 36:758-760.

Rothwell, G.W., M.R. Van Atta, H.E. Ballard, Jr., and R.A. Stockey. 2004. Molecular phylogenetic relationships among Lemnaceae and Aracea using the chloroplast trnL-trnF intergenic spacer. Mol. Phylogenet. Evol. 30:378385 .

Shaw, J., E.B. Lickey, J.T. Beck, S.B. Farmer, W. Liu, J. Miller, K.C. Siripun, C.T. Winder, E.E. Schilling, and R.L. Small. 2005. The tortoise and the hare. II: Relative utility of 21 noncoding chloroplast DNA sequences for phylogenetic analysis. Amer. J. Bot. 92:142-166.

Shaw, J., E. Lickey, E. Schilling, and R. Small. 2007. Comparison of whole chloroplast genome sequences to choose noncoding regions for phylogenetic studies in angiosperms: The tortoise and the hare III. Amer. J. Bot. 94:275.

Stull, G.W., M.J. Moore, V.S. Mandala, N.A. Douglas, H.-R. Kates, X. Qi, S.F. Brockington, P.S. Soltis, D.E. Soltis, and M.A. Gitzendanner. 2013. A targeted enrichment strategy for massively parallel sequencing of angiosperm plastid genomes. Applications in Plant Sciences 1:1200497.

Tsai, C.-C., Y.-C. Chiang, Y.-S. Lin, W.-L. Liu, and C.-H. Chou. 2012. Plastid trnL intron polymorphisms among Phalaenopsis species used for identifying the plastid genome type of Phalaenopsis hybrids. Sci. Hort. 142:84-91.

USDA, National Agriculture Statistics Service and Hawaii Department of Agriculture Agricultural Development Division. 2013. Hawaii flowers and nursery products 2012 annual summary. $<$ http://www.nass.usda.gov/Statistics_by_State/
Hawaii/Publications/Flowers_and_Nursery_ Products/flower.pdf $>$.

Wang, C.-D., J.-H. Niu, Z.-Q. Zhang, H.-B. Pan, and Y. Ren. 2013. Analysis of genetic relationships of Anthurium andreanum varieties using SRAP markers. J. Plant Genet. Resources 14(4):759-763.

Wang, J.-Y. and K.-C. Chuang. 2013. Development of novel microsatellite markers for effective applications in Anthurium cultivar identification. Euphytica 189:421-431.

Wang, R.-J., C.-L. Cheng, C.-C. Chang, C.-L. Wu, T.-M. Su, and S.-M. Chaw. 2008. Dynamics and evolution of the inverted repeatlarge single copy junctions in the chloroplast genomes of monocots. BMC Evol. Biol. $8: 36$.

Wang, W. and J. Messing. 2011. High-throughput sequencing of three Lemnoideae (duckweeds) chloroplast genomes from total DNA. PLoS One 6:e24670.

Wang, W., Y. Wu, Y. Yan, M. Ermakova, R. Kerstetter, and J. Messing. 2010. DNA barcoding of the Lemnaceae, a family of aquatic monocots. BMC Plant Biol. 10:205.

Wu, F.H., M.T. Chan, D.C. Liao, C.T. Hsu, Y.W. Lee, H. Daniell, M.R. Duvall, and C.S. Lin. 2010. Complete chloroplast genome of $\mathrm{On}$ cidium Gower Ramsey and evaluation of molecular markers for identification and breeding in Oncidiinae. BMC Plant Biol. 10:68.

Yang, J.B., M. Tang, H.T. Li, Z.R. Zhang, and D.Z. Li. 2013. Complete chloroplast genome of the genus Cymbidium: Lights into the species identification, phylogenetic implications and population genetic analyses. BMC Evol. Biol. 13:84.

Yu, C., M.-Y. Jin, B.-Z. Zhang, J. Ming, S.-X. Yuan, Z. Wang, L.-H. Chu, and C. Liu. 2012. Genetic linkage map of Anthurium andraeanum based on SRAP molecular markers. Acta Horticulturae Sinica 39:1151-1158. 